Kalem Eğitim ve İnsan Bilimleri Dergisi 2017, 7(2), doi: 10.23863/kalem.2018.92

Makale Gönderim Tarihi:04.11.2016

Makale Kabûl Tarihi:15.03.2017

\title{
Okul Yöneticilerinin ve Öğretmenlerin Çatışma Yönetimi Stillerinin Sosyal Zekâ ve Bazı Kişisel Değişkenlere Göre İncelenmesi ${ }^{1}$
}

\author{
Salih ŞAHIN \\ İstanbul Aydın Üniversitesi, Sosyal Bilimler Enstitüsü, Küçükçekmece / İstanbul / Türkiye, \\ salihogsahin@gmail.com, ORCID: 0000-0001-5451-7708 \\ Prof. Dr. Fulya YÜKSEL-ŞAHIN* \\ Yıldız Teknik Üniversitesi, Eğitim Fakültesi, Davutpaşa Kampüsü, İstanbul / Türkiye, \\ fusahin@yildiz.edu.tr, ORCID: 0000-0003-3454-2142
}

\section{$\ddot{O} z$}

Araştırma, sosyal zekânın, cinsiyetin, kıdemin, yapılan görevin ve medenî durumun öğretmenlerin ve yöneticilerin çatışma yönetimi stilleri düzeyleri üzerindeki etkisini incelemeye yönelik olarak yapılmış olan betimsel bir çalışmadır. 275 öğretmen ve 76 yönetici olmak üzere toplam 351 kişiye uygulama yapılmıştır. Araştırmada gerekli verileri elde etmek için "Tromso Sosyal Zekâ Ölçeği (TSZÖ)”, "Çatışma Yönetimi Stratejileri Ölçeği” ve "Kişisel Bilgiler Formu” kullanılmıştır. Toplanan veriler üzerinde MANOVA, Fisher LSD (En Küçük Anlamlar Farkı) Testi ve $t$ Testi yapıl-

\footnotetext{
${ }^{1}$ İstanbul Aydın Üniversitesi, Sosyal Bilimler Enstitüsü, İşletme Yönetimi Bilim Dalı'nda Salih Şahin tarafından, Prof. Dr. Fulya Yüksel-Şahin'in danışmanlığında hazırlanan yüksek lisans tez çalışmasının özetidir.

* Sorumlu Yazar. Tel: +90 2123834838

(C) 2017 Kalem Eğitim ve Sağlık Hizmetleri Vakfı. Bütün Hakları Saklıdır. ～ISSN: 2146-5606
} 
mıştır. Araştırmanın sonucunda, sosyal zekâ, cinsiyet, kıdem ve yapılan görev değişkenlerinin çatışma yönetimi stilleri üzerinde anlamlı bir etkisi bulunmuştur. Ancak, medenî durum değişkeninin çatışma yönetimi stilleri üzerinde anlamlı bir etkisi bulunmamıştır.

Anahtar Kelimeler: Sosyal zekâ; Çatışma; Çatışma yönetimi; Yönetici; Öğretmen.

\title{
Examination of the Conflict Management Styles of School Administrators and Teachers According to Social Intelligence and Certain Personal Variables
}

\begin{abstract}
This is a descriptive study conducted to examine the effects of social intelligence, gender, seniority, job position, and marital status upon the levels of conflict management styles of teachers and administrators. Study participants include a total of 351 individuals (275 teachers and 76 administrators) employed in the public primary and secondary schools. The "Tromso Social Intelligence Scale (TSIS)", "Conflict Management Strategies Scale”, and a "Personal Information Form" were used to collect the study data. The collected data were subjected to MANOVA, Fisher LSD Test (Least Significant Differences Test) and t-test. As shown by the study results, the variables of social intelligence, gender, seniority, and job position have a significant impact on conflict management styles. On the other hand, marital status as a variable was found to have no significant effect on conflict management styles.
\end{abstract}

Keywords: Social intelligence; Conflict; Conflict management; Administrator; Teacher.

\section{Extended Summary}

\section{Purpose}

Since conflict is inevitable in environments involving people (Weitten, Yost, Hammer and Dunn, 2016), it falls under the fields of psychology, sociology, anthropology, economy and others, in addition to management and organizational psychology (Asunakutlu and Safran, 2004). Individuals, groups, and organizations are in constant interaction when working to realize their goals. In such interactions, controversies, discrepancies (Rahim, 1992; 
cited in Karip, 2000) and discord (Basım, Çetin and Tabak, 2009) in the relationships and activities between parties all create conflict. People from different cultural backgrounds and those with different levels of biological, cognitive, and affective development, perception, cognition, and comprehension skills and values, needs, beliefs, attitudes, preferences, and personality traits who have to share the same environment might naturally lead to conflicts and disagreements in interpersonal relationships (Akkirman, 1998; Türnüklü, 2007). Therefore, it is very important to know how to cope with and manage conflict in a constructive manner (Öner-Körüklü, 2010; Sarpkaya, 2002; Weitten, Yost-Hammer and Dunn, 2016). Successful conflict management involves minimizing the downsides and maximizing the positive aspects of conflicts, optimizing the conflict levels in the organization, and adopting win-win solutions (Akkirman, 1998; Aktan, 1999).

There are five styles of conflict resolution: avoidance, accommodating, competing/forcing, compromising, and collaborating styles (Huan and Yazdanifard, 2012; Thomas, Thomas and Schaubhut, 2008; Weitten, Yost-Hammer and Dunn, 2016). In the light of these approaches to conflict resolution, communication process clearly plays a key role both for the creation and resolution of conflicts (Goldstein, 1999) and effective communication is central to this process (Mayer, 2000). Social intelligence is the type of intelligence required for effective communication (Albert, 2006). Social intelligence is also believed to be a crucial factor in conflict resolution. The present study aims to examine the conflict management styles adopted by school administrators and teachers according to social intelligence and certain personal variables.

\section{Method}

Study participants include a total of 351 individuals (275 teachers and 76 administrators) employed in the public primary and secondary schools in Bahçelievler, Bakırköy, Bağcılar and Küçükçekmece districts on the European side of Istanbul in 2015-2016 academic year. The "Tromso Social Intelligence Scale (TSIS)", "Conflict Management Strategies Scale”, and a "Personal Information Form” were used to collect the study data.

The scales were administered to the participant teachers and administrators for data collection and the collected data were analyzed using SPSS 21 Software Pack. MANOVA, Fisher LSD Test (Least Significant Differences Test) and $t$ test were performed in order to determine whether the conflict 
management strategy levels of the teachers and administrators significantly differ according to social intelligence, gender, seniority, job position, and marital status. The significance level was set to .05 for the study.

\section{Result}

The study examined whether social intelligence significantly affects the conflict management styles of school administrators and teachers. The results revealed significantly higher levels of compromising style, dominating style, and avoiding style among the administrators and teachers with high social intelligence, when compared to those with lower social intelligence. The study also examined the impact of gender upon the conflict management styles of school administrators and teachers and the results demonstrated significantly higher levels of compromising and dominating styles among male administrators and teachers when compared to females. Another point of investigation in this study was the effect of seniority upon the conflict management styles employed by school administrators and teachers. It was found that the lower the seniority of administrators and teachers, the significantly lower the compromising style. The study also investigated the impact of job position (administrator or teacher) upon the conflict management styles of school administrators and teachers. The results showed that the administrators had significantly higher levels of integrating and compromising styles than the teachers. Finally, the study examined the effect of marital status on the conflict management styles of school administrators and teachers, and no significant difference was found between the conflict management styles of school administrators and teachers according to marital status.

\section{Discussion}

The study results revealed significantly higher levels of compromising style, dominating style, and avoiding style among the administrators and teachers with high social intelligence, when compared to those with lower social intelligence. Individuals with high social intelligence are good at resolving conflicts (Selçuk, Kayılı and Okut, 2002). They also have good skills for establishing communication (Loflin and Barry, 2016; Kız1tepe, 2004) and maintaining communication (Doğan, Totan and Sapmaz, 2009). Such individuals easily get into and adapt to social environments (Vaykos, 2015) and know how to act (Karadoğan, 2010; Vural, 2003). They use verbal and non-verbal behaviors effectively (Buzan, 2002'den akt; Doğan ve Çetin, 2009). They are good listeners, empathetic (Praditsang, Hanafi and Walters, 
2015), and grasp people’s feelings (Gardner, 2013; Nagra, 2014). All these traits are important for healthy conflict resolution.

In view of the results of the present study, an individual with high social intelligence may help end or suspend a conflict by using the "dominating" style if the problem persists and if this will cause even greater problems even though he or she has done what needs to be done to resolve that conflict. Thus he or she buys some time for a permanent and healthy solution. As for the avoidance style, administrators and teachers with high levels of social intelligence may ignore conflicts they might have with their employees or students or could allow the other party or parties to win. When it comes to the compromising style, administrators and teachers with high levels of social intelligence could ensure good results for their organizations by compromising in different ways in resolving issues that might arise in their communication with their coworkers and students. For this purpose, rather than simply focusing on their own gains, they may allow the other party or parties to achieve partial gains in order to resolve the problems they might be experiencing.

\section{Conclusion}

The results of this study revealed the importance of providing administrators and teachers with psycho-training group work to improve their social intelligence since social intelligence has an impact upon conflict management styles. Helping administrators and teachers to acquire effective conflict resolution skills is also of importance.

\section{Giriş}

Çatışma, insanların bulunduğu ortamlarda kaçınılmaz olduğu için (Weitten, Yost-Hammer ve Dunn, 2016), yalnızca yönetimin ve örgüt psikolojisinin değil, ayn zamanda psikoloji, sosyoloji, antropoloji, ekonomi ve diğer bilim dallarının da inceleme alanına girmektedir (Asunakutlu ve Safran 2004). Çatışma, çeşitli nedenlerden oluşan birbirine ters düşme, zıtlaşma ve uyumsuzluk hâlidir (Aslan, 2003). Çatışmanın algı, duygu ve davranış boyutları vardır. Algı boyutunda, bireyin kendi gereksinimlerinin, çıkarlarının ya da değerlerinin diğer kişilerle uyuşmadığı algısı vardır. Duygu boyutunda, birtakım uyumsuzluğu işaret eden duruma karşı öfke, korku ya da üzüntü gibi duygular vardır. Davranışsal boyutta ise tarafların konuşmasından şiddete kadar gidebilen davranışları vardır (Mayer, 2000). Çatışma, kişi içi çatışma (Dökmen, 2006), kişiler arası çatışma, kişi ve grup arasındaki çatışma, grupların kendi içinde olan çatışması (Uysal, 2004), bölümler arası çatışma ve 
örgütler arası çatışma olarak ortaya çıkabilir (Yaşlığlu, Pekdemir ve Toplu, 2013).

Bireyler, gruplar ve örgütler amaçlarını gerçekleştirmek için çalışırken sürekli bir etkileşim içindedirler. Bu etkileşim sürecinde taraflar arasındaki ilişkilerde ve etkinliklerde uyuşmazlıklar, tutarsızlıklar (Rahim, 1992'den akt; Karip, 2000) ve geçimsizlikler (Basım, Çetin ve Tabak, 2009) çatışmayı doğurur. Aynı ortamı paylaşmak zorunda olan değişik yapıdaki kültürel özgeçmişleri, biyolojik, zihinsel ve duyuşsal gelişmişlik düzeyleri, algılama, kavrama ve anlama becerileri, değer, gereksinim, inanç, tutum, seçim ve kişilik özellikleri doğal olarak insan ilişkilerinde kişiler arası çatışmaya ve anlaşmazlıklara yol açabilmektedir (Akkirman, 1998; Türnüklü, 2007). Her kurumda olduğu gibi okullarda da görev dağılımı, parasal kaynaklar, sınıf içi öğretim etkinlikleri, ödül, ceza, değerlendirme, güç ve yetki kullanımı, geç gelme, izin, siyasî konular, öğrenci davranışları, kılık-kıyafet, tayin ve kaynak dağılımı gibi konularda çatışma çıkabilmektedir (Karip, 2000). Doğal olarak, okul ortamında bazı anlaşmazlıkların olması kaçınılmazdır. Yöneticiler ve öğretmenler, okulda meydana gelebilecek muhtemel çatışmaları önlemek için gerekli çabayı göstermelidirler (Titrek, Maral ve Barut-Kızılkaya, 2015). Çatışma çıktığında da bu çatışma durumlarını okulun ortak amaçları çerçevesinde, okulun yararına yönlendirebilmelidirler. Hem yöneticilerin, hem de öğretmenlerin bu tür çatışmaları birer firsat bilerek hareket etmeleri gerekir. Bunun için, öncelikle yapılması gereken, ortaya çıkan çatışmaları derinlemesine irdelemek ve çatışma nedenlerini ortaya çıkartmaktır. Daha sonra, çatışmaları olumlu bir şekilde sonlandırma adına farklı yöntemleri sabırla uygulamaktır (Bayar, 2015).

Çatışma, kötü ve bastırılması gereken bir durum olarak düşünülmemelidir. Gerçekte çatışma ne tamamen iyidir, ne de kötüdür. İnsanların çatışma ile nasıl başa çıktıklarına bağlı olarak iyi ya da kötü sonuçları doğuran bir olgudur. Bu nedenle, çatışma ile yapıcı bir biçimde nasıl başa çıkılabileceğinin bilinmesi ve yönetilmesi çok önemlidir (Öner-Körüklü, 2010; Sarpkaya, 2002; Weitten, Yost-Hammer ve Dunn, 2016). Çatışma yönetimi, anlaşmazlığı belirli bir amaç doğrultusunda sonuca ulaştırabilmek için çatışmaya taraf olanların ya da üçüncü tarafın karşılıklı olarak bir dizi eylemde bulunmasıdır. Eylemler çatışmanın sona erdirilmesine yönelik olabileceği gibi çatışma sürecinin etkinleşmesini sağlamaya yönelik de olabilir. Çatışma yönetiminin amacı olumlu, barışçıl ve uzlaşmacı bir biçimde çatışmayı sonlandırmak 
olabileceği gibi, karşı tarafa üstünlük kurmaya yönelik de olabilir (Ross, 1993'den akt; Karip, 2000). Başarılı bir çatışma yönetiminde, çatışmaların olumsuz yanlarını en aza indirmek, yararlı yönlerini en üst düzeye çıkartmak, örgütteki çatışma düzeyini optimum (en iyi) düzeyde tutmak ve çatışmalarda kazan-kazan çözüm biçimini benimsemek vardır (Akkirman, 1998; Aktan, 1999).

Çatışmayla başa çıkmanın beş farklı örüntüsü bulunmaktadır. Bunlar; kaçınma (geri çekilme), uyma (ödün verme-itaat etme), hükmetme (zorlamayarışma-üstünlük kurma), uzlaşma (karşılıklı ödün verme) ve işbirliğidir (bütünleştirme-tümleştirme-pazarlık) (Bayar, 2015; Huan ve Yazdanifard, 2012; Thomas, Thomas ve Schaubhut, 2008; Weitten, Yost-Hammer ve Dunn, 2016). Kaçınma stilinde birey, çatışma yaşadığında çok rahatsız olur. Konuyu kapatır ya da değiştirir. Sorunu görmezden gelince sorunun ortadan kalkacağını düşünür. Küçük sorunlar için iyi bir stil olabilir. Ancak büyük sorunlarda iyi bir stil değildir. Uyma stilinde, birey çatışma yaşadığında çok rahatsız olur. Çatışmadan vazgeçer ve çatışmayı hızlıca sonlandırır. Bu stilde, yaratıcı düşünme ve etkili çözümler bulunmadığı için zayıf bir stildir. Bu stili benimseyen kişilerin başkaları tarafından onaylanma ve kabul görme konusunda aşırı kaygıları vardır. Hükmetme (zorlama-yarışma-üstünlük kurma) stilinde, kişi her çatışmayı siyah-beyaza dönüştürebilir. Burada kazanmak ya da kaybetmek vardır. Hükmetme stilini benimseyen kişi her çatışmadan galip çıkmaya çalıştığı için baskı, tehdit, sözlü saldırı ya da fiziksel tehdidi kullanarak saldırgan davranışları gösterebilirler. Bu stilde de yaratıcı düşünme ve etkili çözümler bulunmadığı için zayıf bir stildir. Uzlaşma stilinde, her iki tarafın ihtiyaçlarından doğan ayrışmalar kabul edilir. Karşı tarafın isteklerini karşılamaya açıktırlar. Her iki taraf, ödün verebilir. Böylece karşılıklı doyum sağlanır. $\mathrm{Bu}$ nedenle uzlaşma stili, yapıcı bir stildir. İşbirliği (bütünleştirme-tümleştirme) stilinde ise çatışma, mümkün olan en etkili bir biçimde çözülmesi gereken ortak bir sorun olarak değerlendirilir. En yapıcı stildir (Weitten, Yost-Hammer ve Dunn, 2016). Bu beş farklı örüntülerin oluşmasında iki temel faktör vardır. Bu iki faktör ise bireyin kendi kaygılarını ortadan kaldırma isteği ve başkalarının kaygılarını ortadan kaldırma isteğidir (Brewer, Mitchell ve Weber, 2002).

Çatışma çözümüne yönelik yukarıda ele alınan yaklaşımlara bakıldığında çatışmaların hem nedeni hem de çözümü açısından iletişim sürecinin rolü ön plana çıkmaktadır (Goldstein, 1999) ve merkezde de etkili iletişim 
vardır (Mayer, 2000). Etkili bir şekilde iletişim kurabilmek için gereken zekâ, sosyal zekâdır (Albert, 2006). Çatışma çözmede de sosyal zekânın önemli bir faktör olduğu düşünülmektedir. Çatışma yaşayan insanların iş yaşamlarında ya da günlük yaşamlarında stres düzeylerinin yükselmesiyle birlikte anlık duygu patlamaları ve öfkeli durumlar ortaya çıkabilmektedir. Bu durumda kişinin matematiksel zekâsı, duygusal zekâsı yetersiz kalmakta; ve farklı bir yeteneğin devreye girerek bu sorunun çözümünü sağlaması gerekmektedir. İşte bu durumda devreye giren sorunun çözümünde etkin rol oynayan zekâ, sosyal zekâdır (Özülke, 2015). Nitekim, Selçuk, Kayılı ve Okut (2002), sosyal zekâsı yüksek olan bireylerin çatışmaları çözmede başarılı olduklarını belirtmektedirler.

Sosyal zekâ Thorndike’a göre, insanları anlama ve idare etme yeteneğidir (Goleman, 2014). Sosyal zekâ, insanları anlayabilmek ve onlarla başarılı bir şekilde iletişim kurabilmek için gereken beceri unsurlarının birleşimidir. Başkaları ile iyi geçinebilme ve işbirliği yapmalarını sağlayabilme yeteneğidir (Albert, 2006). Diğer insanların ruh hâllerine, mizaçlarına, motivasyonlarına ve amaçlarına gösterilen hassasiyet gibi başkaları ile iletişim kurarken kullanılan becerilerdir (Renner ve Feldman, 2015). Sosyal zekâ yalnızca bireyin kendinde ya da karşısındakinde değil, çevresinde olup bitenleri de anlama etkileyebilme ve farklı sosyal ortamlarda iyi ilişkiler kurabilme kapasitesidir (Terwase, Ibaishwa ve Enemari, 2016).

Sosyal zekâ, diğer insanları tanımak ve onlarla başarılı bir etkileşim içerisinde olmak için kullanılır. Sosyal zekâsı yüksek olan insanlar, insanlarla ilgilenmek, onlarla birlikte çalışmak, onlarla birlikte öğrenmek ve onlara öğretmekten zevk alırlar (Selçuk, Kayılı ve Okut, 2002). Benlik saygıları yüksektir (Vaykos, 2015). İş yaşamında çalışanlarla nitelikli ilişkiler kurarak başarılı sonuçlar alınmasında etkili olurlar. Sosyal zekâsı yüksek insanlar farklı kültür, yaş ve ırktan insanlarla rahat bir ilişki kurabilirler ve onların kendilerini rahat hissetmelerini sağlayabilirler. Beden dilini etkili biçimde kullanırlar (Buzan, 2002'den akt; Doğan ve Çetin, 2009), iyi bir dinleyicidirler (Praditsang, Hanafi ve Walters, 2015), yargilamadan dinlerler (Bümen, 2004), empati becerileri gelişmiştir (Praditsang, Hanafi ve Walters, 2015), insanların duygularını anlarlar (Nagra, 2014). Diğer insanların isteklerini, arzularını (Gardner, 2013), sevinç ve kızgınlıklarını anlayabilme, bunlara göre davranışlarını ayarlayabilme ve diğerlerini etkileyip yönlendirebilme yeteneğine de sahiptirler (Kızlltepe, 2004). Samimidirler. Sosyal ortamlara ve 
çevrelere kolayca girebilirler ve uyum sağlarlar (Vaykos, 2015). Kendilerini başarılı bir biçimde karışısındaki kişilere tanıtılar, başkalarını etkilerler (Praditsang, Hanafi ve Walters, 2015), sosyal ortamda etkindirler, poblem çözerler, ikna edebilirler ve sosyal ortamlarda nasıl davranacağını bilirler (Karadoğan, 2010). Arkadaş ilişkileri iyidir, yaşamlarında başarılıdırlar ve liderlik becerileri yüksektir (Selçuk, Kayılı ve Okut, 2002). Sosyal zekâya sahip kişiler başkalarıyla iyi gecinebilme, iyi iletişim kurabilme (Loflin ve Barry, 2016; Kızlltepe, 2004) ve bu iletişimi sürdürebilme becerisine sahiptirler (Doğan, Totan ve Sapmaz, 2009). Aile içi sorunları gidermede ve çatışmaları çözmede başarılıdırlar (Selçuk, Kayılı ve Okut, 2002).

Yukarıdaki açıklamaların 1şığında, sosyal zekâsı yüksek olan yöneticilerin ve öğretmenlerin, görev yaptıkları okullarda ortaya çıkacak olan çatışmaları çözmede daha başarılı olabilecekleri düşünülmektedir. Bu araştırmanın amacı da okul yöneticilerin ve öğretmenlerin çatışma yönetimi stillerinin sosyal zekâ ve bazı kişisel değişkenlere göre incelemektir. Alanyazında, kişilik özellikleri ile çatışma yönetimi stilleri (Antonioni, 1998); öfke ve stresle başa çıkma yaklaşımları ile çatışma yönetimi stilleri (Gündüz, Tunç ve İnand1, 2013); duygusal zekâ ile çatışma yönetimi stilleri (Carmody-Bubb, Duncan ve Ree, 2015; Monteiro ve Balogun, 2015; Pandey, Sajjanapu ve Sangwan, 2015); kültürel zekâ ile çatışma yönetimi stilleri (Gonçalves, Reis, Sousa ve Santos, 2016) arasındaki ilişkiyi inceleyen araştırmalar mevcuttur. Ancak, sosyal zekâ ile çatışma yönetimi stilleri arasındaki ilişkiyi inceleyen araştırmalara rastlanılamamıştır. Bu açıdan bakıldığında bu araştırmanın alan yazına bir ölçüde de olsa katkı sağlayacağı düşünülmektedir.

\section{Yöntem}

Araştırma, sosyal zekânın, cinsiyetin, kıdemin, yapılan görevin ve medenî durumun öğretmenlerin ve yöneticilerin çatışma yönetimi stilleri üzerindeki etkisini incelemeye yönelik olarak yapılmış olan betimsel bir çalışmadır.

\section{Evren ve Örneklem}

Araştırmanın evreni, ulaşılabilen evrendir. Araştırmadan elde edilen sonuçlar, ancak bu sınırlı evrene genellenebilir (Büyüköztürk, Kılıç-Çakmak, Akgün, Karadeniz ve Demirel, 2009). Araştırmanın örneklemini, 2015-2016 Eğitim-Öğretim yılında, İstanbul İli Avrupa Yakasındaki Bahçelievler, Bakırköy, Bağcılar ve Küçükçekmece resmî ilkokul, ortaokul ve liselerde görev yapan 275 öğretmen ve 76 okul yöneticisi olmak üzere toplam 351 kişi 
oluşturmuştur. Araştırmaya katılan öğretmenlerin ve yöneticilerin 169'u (\%48.1) kadın, 182'si (\%51.9)'i erkeklerden oluşmaktadır. Yapılan göreve göre 15'i (\%4.3) okul müdürü, 7'si (\%2) müdür başyardımcısı, 54'ü (\%15.4) müdür yardımc1 ve 275'i (\%78.3) öğretmendir. Öğretmenlerin ve yöneticilerin 249’u (\%70.90) evli, 98'i (\%27.9) bekâr ve 4’ü (\%1.1) boşanmıştır. Ayrıca, yöneticilerin 60'1 (\%17.1) 0-5 yı1, 55'i (\%15.7) 6-11yı1, 111'i (\%31.6) 12-17 yıl, 74'ü (\%21.1)'ü 18-23 yıl ve 51'i (\%14.5)'i 24 yıl ve üstü kıdeme sahiptir.

\section{Veri Toplama Araçları}

Araştırmada gerekli verileri elde etmek için "Tromso Sosyal Zekâ Ölçeği (TSZÖ)", "Çatışma Yönetimi Stratejileri Ölçeği” ve "Kişisel Bilgiler Formu" kullanılmıştır.

Tromso Sosyal Zekâ Ölçeği (TSZÖ): Ölçek, kişilerin sosyal zekâ düzeyini belirlemek üzere Silvera ve arkadaşları tarafından 2001 yılında geliştirilmiştir (Doğan ve Çetin, 2009). 21 maddeden oluşan 5'li likert tipi bir ölçektir. Ölçekten alınan yüksek puanlar yüksek sosyal zekâya sahip olduğunu gösterirken, düşük puanlar düşük sosyal zekâya sahip olduğunu göstermektedir. Ölçek, sosyal zekâyı sosyal bilgi süreci, sosyal beceri ve sosyal farkındalık olarak üç ayrı alana ayırarak ölçmektedir. Ölçeğin Türkiye'deki geçerlik ve güvenirlik çalışmaları Doğan ve Çetin (2009) tarafından yapılmıştır. Ölçeğin, testin tekrarı yönteminde hesaplanan toplam puana ilişkin güvenirlik katsayısı .80'dir. Alt ölçeklerde ise sosyal bilgi için .68, sosyal beceriler için .81 ve sosyal farkındalık için .95 bulunmuştur. Ölçeğin, Cronbach alfa katsayısı yöntemi ile hesaplanan toplam puana ilişkin güvenirlik katsayısı Cronbach alfa .83 olarak bulunmuştur. Alt ölçeklerde ise sosyal bilgi süreci için .77, sosyal beceri için .85 ve sosyal farkındalık için .67 bulunmuştur. Ölçeğin, test yarılama yöntemiyle hesaplanan toplam puana ilişkin güvenirlik katsayısı .75’tir. Alt ölçeklerde ise sosyal bilgi süreci için .76, sosyal beceri için .83 ve sosyal farkındalık için .71 bulunmuştur.

Ölçeğin geçerlik çalışmaları için kapsam geçerliği ve benzer ölçekler geçerliğine bakılmıştır. Kapsam geçerliği ile ilgili çalışmada uzman kanısına başvurulmuştur. Alanda uzman olarak çalışan kişiler TSZÖ’nün incelenmesi sonucu sosyal zekâ düzeyini ölçebilecek nitelikte olduğu yönünde görüş belirtmişlerdir. Ölçeğin benzer ölçek geçerliği çalışmasında, benzer ölçekler geçerliğini saptamak üzere Yüksel (1997) tarafindan Türkçeye uyarlanan Sosyal Beceri Envanteri (SBE) kullanılmıştır. TSZÖ’i Hacettepe Kişilik 
Envanteri (HKE) Sosyal İlişkiler Alt Ölçeği birlikte uygulanmıştır. İki ölçekten elde edilen puanlar arasında $.41(n=83)$ bulunmuştur. TSZÖ’nün alt ölçekleri ile HKE Kişilerarası İlişkiler Alt Ölçeği arasındaki korelasyon katsayıları ise .18 ile .56 arasında değişmektedir. TSZÖ’i ve Sosyal Beceri Envanteri (SBE) birlikte uygulanmıştır. Her iki ölçekten elde edilen puanlar arasında $.51(\mathrm{n}=134)$ bulunmuştur. TSZÖ'nün alt ölçekleri ile SBE arasındaki korelasyon katsayıları ise .05 ile .61 arasında değişmektedir. Yapılan bu çalışmalardan elde edilen sonuçlar TSZÖ’nün yeterli düzeyde geçerlik ve güvenirlik değerlerine sahip olduğunu göstermektedir (Doğan ve Çetin, 2009).

Rahim Örgütsel Çatışma Ölçeği (ROCI II): Ölçek, Rahim tarafından 1983 yılında geliştirilmiş; ölçeğin Türkçeye uyarlaması Gümüşeli (1994) tarafından yapılmıştır. 28 maddelik, 5'li likert tipi bir ölçektir. Test tekrar test güvenirlik yöntemi ile elde edilen korelasyon katsayısı yöneticiler için .81, öğretmenler için .88 bulunmuştur. Ölçeğin, geçerlik çalışması Altıntaş (2007) tarafından yapılmıştır. Açımlayıcı faktör analizi ve ortaya çıkan faktör yapısını sınamak için doğrulayıcı faktör analizi yapılmıştır. Ölçeğin işbirliği, uzlaşma, kaçınma, hükmetme ve uyma alt boyutları vardır. Birinci faktörde yer alan 13 maddenin işbirliği ve uzlaşma maddelerini içerdiği göz önünde tutularak bu alt boyut işbirliği-uzlaşma olarak adlandırılmıştır. Bu faktör toplam varyansın \%25.89'unu açıklamaktadır. Diğer üç faktör (kaçınma, hükmetme, uyma), özgün ölçekle benzerlik göstermektedir. Kaçınma alt boyutu toplam varyansın \%9.28'ini açılamaktadır. Hükmetme alt boyutu toplam varyansın \%8.49'unu açıklamakta, dört madde içermektedir. Uyma alt boyutu ise toplam varyansın \%5.62'sini açıklamaktadır.

Kişisel Bilgi Formu: Araştırmacı tarafından geliştirilmiş olan formda cinsiyete, kıdeme, yapılan göreve ve medenî duruma ilişkin sorular bulunmaktadır. Formun başında araştırmanın amacı yer almıştır. Değerlendirmenin bireysel değil, toplu yapılacağı belirtilerek isim yazılmaması istenmiştir.

\section{Verilerin Analizi}

Verilerin toplanması amacı ile ölçekler öğretmenlere ve yöneticilere uygulanmıştır. Verilerin çözümlenmesinde SPSS 21 paket programından yararlanılmıştır. Araştırmada, öğretmenlerin ve yöneticilerin çatışma yönetimi stilleri düzeylerinin sosyal zekâya, cinsiyete, kıdeme, yapılan göreve ve medenî duruma göre anlamlı bir farklılık gösterip göstermediğini belirleyebilmek için MANOVA, Fisher LSD (Least Significant Differences Test/En 
Küçük Anlamlar Farkı) Testi ve $t$ Testi (Büyüköztürk, 2002) yapılmıştır. Araştırmada, anlamlılık düzeyi .05 olarak alınmıştır.

\section{Bulgular}

Bu bölümde, araştırmada ele alınan problemin çözümü için toplanan verilerin istatistiksel çözümlenmesi sonucunda elde edilen bulgulara ilişkin ulaşılan sonuçlara yer verilmiştir.

Problemin çözümü için öncelikle Tromso Sosyal Zekâ Ölçeği'nden (TSZÖ) ve Örgütsel Çatışma Ölçeği'nden (ROC II) elde edilen puanların normal dağılım gösterip göstermediğini belirlemek için alınan puanların çarpıklık katsayılarına (Skewness) ve basıklık (Kurtosis) katsayılarına bakılmıştır. Çarpıklık (Skewness) katsayılarına bakıldığında, Tromso Sosyal Zekâ Ölçeği (TSZÖ) için .734'dir. Örgütsel Çatışma Ölçeği (ROC II) için katsayıları, tümleştirme boyutu için -.282, ödün verme boyutu için .173, hükmetme boyutu için .384, kaçınma boyutu için -.150, uzlaşma boyutu için -.229 ve toplam puanda .089 olmuştur. Basıklık (Kurtosis) katsayılarına bakıldığında, Tromso Sosyal Zekâ Ölçeği (TSZÖ) için 1.095'dir. Örgütsel Çatışma Ölçeği (ROC II) için katsayıları, tümleştirme boyutu için .188, ödün verme boyutu için .008, hükmetme boyutu için .057 , kaçınma boyutu için -.367, uzlaşma boyutu için .387 ve toplam puanda .109 olmuştur. Bu puan dağılımları, normal dağılım göstermektedir. Herhangi bir veri grubunda çarpıklık ve basıklık değerinin $+1,-1$ aralığında olmasının normal dağılım için kabul edilebilir düzeyde olmasının yanı sıra (Yıldızoğlu ve Burgaz, 2014), bu değerin $+2,-2$ aralığında olması da genellikle kabul edilebilir bir durum olarak görülmektedir (Cooper-Cutting, 2010'den akt; Arapkirlioğlu ve Tank1z, 2011).

Ayrıca Durbin-Watson Testi de yapılmıştır. Genellikle 1.5-2.5 Durbin-Watson Testi değeri, otokorelasyon olmadığını gösterir (Taşdan ve Erdem, 2010). Sosyal Zekâ ve Çatışma Yönetimi Stilleri için DW=1.84; Cinsiyet ve Çatışma Yönetimi Stilleri için DW=1.86; Kıdem ve Çatışma Yönetimi Stilleri için DW=1.90; Yapılan Görev ve Çatışma Yönetimi Stilleri için DW=1.89 ve Medenî Durum ve Çatışma Yönetimi Stilleri için DW=1.86'dır. Durbin-Watson Testi sonucunda da otokorelasyon olmadığı da görülmüştür.

Araştırmada, sosyal zekâya göre okul yöneticilerinin ve öğretmenlerin çatışma yönetimi stilleri arasında anlamlı bir farklılık olup olmadığını belirlemek için MANOVA analizi yapılmış ve sonuçları Tablo 1'de gösterilmiştir. 
Tablo 1. Sosyal Zekâya Göre Okul Yöneticilerinin ve Öğretmenlerin Çatışma Yönetimi Stilleri Arasındaki Farklılığa İlişkin MANOVA Analiz Sonuçları

\begin{tabular}{llccccc}
\hline Kaynak & Değişkenler & $\begin{array}{c}\text { Kareler } \\
\text { Toplamı }\end{array}$ & Sd & $\begin{array}{c}\text { Kareler } \\
\text { Ortalaması }\end{array}$ & F & $\boldsymbol{p}$ \\
\hline \multirow{3}{*}{ Sosyal } & Tümleştirme & 9.09 & 1 & 9.09 & 1.05 & .30 \\
Zekâ & Ödün & 87.26 & 1 & 87.26 & $11.05^{*}$ & .00 \\
& Hükmetme & 61.26 & 1 & 61.26 & $6.41^{*}$ & .01 \\
& Kaçınma & 140.73 & 1 & 140.73 & $10.55^{*}$ & .00 \\
& Uzlaşma & 7.89 & 1 & 7.89 & 1.17 & .28 \\
\hline
\end{tabular}

Wilks' Lambda $(\Lambda)=.932$, F hesaplanan $(5,345)=5.04, p<.00$

Tablo 1'de görülen MANOVA sonuçları, sosyal zekâya göre $(\Lambda=.932$, $F$ hesaplanan $(5,345)=5.04, p<.00)$ yöneticilerin ve öğretmenlerin çatışma yönetimi stilleri puanlarının anlamlı olarak farklılık gösterdiğini ortaya koymuştur. Ayrıca, MANOVA uzantısında yer alan ANOVA sonuçlarına bakıldığında ise çatışma yönetimi stilleri alt boyutlarından ödün ( $F$ hesaplanan=11.05, $p<.00$ ), hükmetme ( $F$ hesaplanan $=6.41, p<.01)$ ve kaçınma $(F$ hesaplanan $=10.55, p<.00)$ puanlarının da anlamlı olarak farklılık $(p<.05)$ gösterdiği bulunmuştur.

Sosyal zekâya göre okul yöneticilerinin ve öğretmenlerin çatışma yönetimi stillerinin alt boyutları olan ödün, hükmetme ve kaçınma ile toplam çatışma yönetimi stilleri puanlarının anlamlı olarak farklılık gösterdiğine ilişkin olarak Bağımsız Gruplarda $t$ Testi yapılmış ve sonucu da Tablo 2'de sunulmuştur.

Tablo 2. Yöneticilerin ve Öğretmenlerin Çatışma Yönetimi Stilleri Düzeylerinin Sosyal Zekâya Göre Bağımsız Gruplarda $t$ Testi Sonuçları

\begin{tabular}{lccccc}
\hline Sosyal Zekâ & $\mathbf{N}$ & $\overline{\mathrm{X}}$ & ss & $\mathbf{t}$ & $\boldsymbol{p}$ \\
\hline Ödün & & & & & \\
S.Z. Düşük & 199 & 14.08 & 2.79 & $3.32^{*}$ & .00 \\
S.Z. Yüksek & 152 & 15.39 & 8.63 & & \\
\hline Hükmetme & & & & & \\
S.Z. Düşük & 199 & 12.22 & 3.08 & $2.53^{*}$ & .01 \\
S.Z. Yüksek & 152 & 13.06 & 3.11 & & \\
\hline Kaçınma & & & & & \\
S.Z. Düşük & 199 & 17.37 & 3.53 & $3.25^{*}$ & .00 \\
S.Z. Yüksek & 152 & 18.64 & 3.80 & & \\
\hline
\end{tabular}

Tablo 2'de görüldüğg̈ gibi sosyal zekâs1 yüksek olan yöneticilerin ve öğretmenlerin ödün puan ortalaması $(\overline{\mathrm{X}}=15.39)$, sosyal zekâsı düşük olan 
yöneticilerin ve öğretmenlerin ödün puan ortalamasından $(\overline{\mathrm{X}}=14.08)$ anlamlı düzeyde ( $\mathrm{t}=3.32, p<.00)$ yüksek çıkmıştır. Sosyal zekâsı yüksek olan yöneticilerin ve öğretmenlerin hükmetme puan ortalaması $(\overline{\mathrm{X}}=13.06)$, sosyal zekâs1 düşük olan yöneticilerin ve öğretmenlerin hükmetme puan ortalamasından $(\overline{\mathrm{X}}=12.22)$ anlamlı düzeyde $(\mathrm{t}=2.53, p<.01)$ yüksek çıkmıştır. Sosyal zekâsı yüksek olan yöneticilerin ve öğretmenlerin kaçınma puan ortalaması ( $\bar{X}=18.64)$, sosyal zekâsı düşük olan yöneticilerin ve öğretmenlerin kaçınma puan ortalamasından $(\overline{\mathrm{X}}=17.37)$ anlamlı düzeyde $(\mathrm{t}=3.25, p<.00)$ yüksek çıkmıştır. Sosyal zekâsı yüksek olan yöneticilerin ve öğretmenlerin ödün stilini, hükmetme stilini ve kaçınma stilini kullandıkları bulunmuştur.

Araştırmada, cinsiyete göre okul yöneticilerinin ve öğretmenlerin çatışma yönetimi stilleri arasında anlamlı bir farklılık olup olmadığını belirlemek için MANOVA analizi yapılmış ve sonuçları Tablo 3'te gösterilmiştir.

Tablo 3. Cinsiyete Göre Okul Yöneticilerinin ve Öğretmenlerin Çatışma Yönetimi Stilleri Arasındaki Farklılığa İlişkin MANOVA Analiz Sonuçları

\begin{tabular}{llccccc}
\hline Kaynak & Değişkenler & $\begin{array}{c}\text { Kareler } \\
\text { Toplamı }\end{array}$ & Sd & $\begin{array}{c}\text { Kareler } \\
\text { Ortalaması }\end{array}$ & $\mathbf{F}$ & $\boldsymbol{p}$ \\
\hline Cinsiyet & Tümleştirme & 2.480 & 1 & 2.480 & .29 & .59 \\
& Ödün & 78.966 & 1 & 78.966 & $9.97^{*}$ & .00 \\
& Hükmetme & 73.441 & 1 & 73.441 & $7.71^{*}$ & .00 \\
& Kaçınma & 32.686 & 1 & 2.686 & 2.40 & .12 \\
& Uzlaşma & .391 & 1 & .391 & .06 & .81 \\
\hline
\end{tabular}

Wilks' Lambda $(\Lambda)=.946$, F hesaplanan $(6,344)=3.26, p<.00$

Tablo 3'te görülen MANOVA sonuçları, cinsiyete göre $(\Lambda=.946, F$ hesaplanan $(6,344)=3.26, p<.00$ ) yöneticilerin ve öğretmenlerin çatışma yönetimi stilleri puanlarının anlamlı olarak farklılık gösterdiğini ortaya koymuştur. Ayrıca, MANOVA uzantısında yer alan ANOVA sonuçlarına bakıldığında ise çatışma yönetimi stilleri alt boyutlarından ödün ( $F$ hesaplanan=9.97, $p<.00$ ) ve hükmetme ( $F$ hesaplanan=7.71, $p<.00)$ puanlarının da anlamlı olarak farklılık $(p<.05)$ gösterdiği bulunmuştur.

Cinsiyete göre okul yöneticilerinin ve öğretmenlerin çatışma yönetimi stillerinin alt boyutları olan ödün ve hükmetme puanlarının anlamlı olarak farklılık gösterdiğine ilişkin olarak Bağımsız Gruplarda $t$ Testi yapılmış ve sonucu Tablo 4'te sunulmuştur. 
Tablo 4. Yöneticilerin ve Öğretmenlerin Ödün ve Hükmetme Stillerinin Cinsiyete Göre Bağımsız Gruplarda $t$ Testi Sonuçları

\begin{tabular}{lccccc}
\hline Cinsiyet & $\mathbf{N}$ & $\overline{\mathrm{X}}$ & $\mathbf{s s}$ & $\mathbf{t}$ & $\boldsymbol{p}$ \\
\hline Ödün & & & & & \\
$\quad$ Kadın & 169 & 14.33 & 2.92 & 3.16 & .00 \\
$\quad$ Erkek & 182 & 15.27 & 2.71 & & \\
\hline Hükmetme & & & & & \\
$\quad$ Kadın & 169 & 12.11 & 3.19 & 2.78 & .01 \\
$\quad$ Erkek & 182 & 13.02 & 2.99 & & \\
\hline
\end{tabular}

Tablo 4'te görüldüğü gibi erkek olan yöneticilerin ve öğretmenlerin ödün puan ortalaması ( $\overline{\mathrm{X}}=15.27)$, kadın olan yöneticilerin ve öğretmenlerin ödün puan ortalamasından $(\overline{\mathrm{X}}=14.33)$ anlamlı düzeyde $(\mathrm{t}=3.16, p<.00)$ yüksek çıkmıştır. Erkek olan yöneticilerin ve öğretmenlerin hükmetme puan ortalaması ( $\overline{\mathrm{X}}=13.02)$, kadın olan yöneticilerin ve öğretmenlerin hükmetme puan ortalamasından $(\overline{\mathrm{X}}=12.11)$ anlamlı düzeyde $(\mathrm{t}=2.78, p<.01)$ yüksek çıkmıştır. Erkek yöneticilerin ve öğretmenlerin ödün stili ve hükmetme stili kadınlardan daha fazla çıkmıştır.

Araştırmada, kıdeme göre okul yöneticilerinin ve öğretmenlerin çatışma yönetimi stilleri arasında anlamlı bir farklılık olup olmadığını belirlemek için MANOVA analizi yapılmış ve sonuçları Tablo 5'te gösterilmiştir.

Tablo 5. Kıdeme Göre Okul Yöneticilerinin ve Öğretmenlerin Çatışma Yönetimi Stilleri Arasındaki Farklılığa İlişkin MANOVA Analiz Sonuçları

\begin{tabular}{llccccc}
\hline Kaynak & Değişkenler & $\begin{array}{c}\text { Kareler } \\
\text { Toplamı }\end{array}$ & Sd & $\begin{array}{c}\text { Kareler } \\
\text { Ortalaması }\end{array}$ & F & $\boldsymbol{p}$ \\
\hline Kıdem & Tümleştirme & 68.81 & 4 & 17.220 & 2.01 & .09 \\
& Ödün & 77.97 & 4 & 19.491 & $2.44 *$ & .05 \\
& Hükmetme & 72.26 & 4 & 18.065 & 1.88 & .11 \\
& Kaçınma & 92.55 & 4 & 23.137 & 1.70 & .15 \\
& Uzlaşma & 54.07 & 4 & 13.517 & 2.04 & .09 \\
\hline
\end{tabular}

Wilks' Lambda $(\Lambda)=.913$, F hesaplanan $(20.000,1135.236)=1.59, p<.05$

Tablo 5'te görülen MANOVA sonuçları, kıdeme göre $(\Lambda=.913, F$ hesaplanan $(20.000,1135.236)=1.59, p<.05)$ yöneticilerin ve öğretmenlerin çatışma yönetimi stilleri puanlarının anlamlı olarak farklılık gösterdiğini ortaya koymuştur. Ayrıca, MANOVA uzantısında yer alan ANOVA sonuçlarına bakıldığında ise çatışma yönetimi stilleri alt boyutundan ödün ( $F$ hesaplanan $=2.44, p<.05)$ puanlarının da anlamlı olarak farklılık gösterdiğ bulunmuştur. 
Kıdeme göre okul yöneticilerinin ve öğretmenlerin çatışma yönetimi stillerinin alt boyutu olan ödün puanının anlamlı olarak farklılık gösterdiğine ilişkin olarak Fisher LSD (Least Significant Differences Test/En Küçük Anlamlar Farkı) testi yapılmış ve sonucu Tablo 6'da sunulmuştur.

Tablo 6. Yöneticilerin ve Öğretmenlerin Ödün Stilinin Kıdeme Göre LSD Testi Sonuçları

\begin{tabular}{lcccccc}
\hline $\begin{array}{l}\text { Ödün Stili ve } \\
\text { Kıdem }\end{array}$ & $\overline{\mathrm{X}}$ & $\begin{array}{c}\mathbf{0 - 5} \\
\text { Yıl }\end{array}$ & $\begin{array}{c}\mathbf{6 - 1 1} \\
\text { Yıl }\end{array}$ & $\begin{array}{c}\mathbf{1 2 - 1 7} \\
\text { Yıl }\end{array}$ & $\begin{array}{c}\mathbf{1 8 - 2 3} \\
\text { Yıl }\end{array}$ & $\begin{array}{c}\mathbf{2 4} \\
\text { Yıl + }\end{array}$ \\
\hline Kıdem & & & & & & \\
$0-5$ Yil $(\mathrm{n}=60)$ & 14.20 & - & .05 & .88 & 1.16 & 070 \\
6-11 Y11 (n=55) & 14.15 & & - & $.94 *(p<.05)$ & $1.22 *(p<.02)$ & .76 \\
12-17 Y1l (n=111) & 15.08 & & & - & .28 & .18 \\
18-23 Yil (n=74) & 15.36 & & & & - & .46 \\
24 Yil $+(\mathrm{n}=51)$ & 4.90 & & & & & - \\
\hline
\end{tabular}

Tablo 6'da görüldüğü gibi kıdemi 6-11 y1l olan yöneticilerin ve öğretmenlerin ödün puan ortalaması $(\bar{X}=14.15)$, kıdemi $12-17$ y1l olan yöneticilerin ve ögretmenlerin ödün puan ortalamasından $(\overline{\mathrm{X}}=15.08)$ anlamlı düzeyde $(p<.05)$ düşük çıkmıştır. Kıdemi 6-11 yıl olan yöneticilerin ve öğretmenlerin ödün puan ortalaması ( $\overline{\mathrm{X}}=14.15)$, k1demi $18-23$ y1l olan yöneticilerin ve ögretmenlerin ödün puan ortalamasından $(\bar{X}=15.36)$ anlamlı düzeyde $(p<.02)$ düşük çıkmıştır. Yöneticilerin ve öğretmenlerin kıdemi azaldıkça ödün stili de azalmaktadır.

Araştırmada, yapılan göreve göre okul yöneticilerinin ve öğretmenlerin çatışma yönetimi stilleri arasında anlamlı bir farklılık olup olmadığını belirlemek için MANOVA analizi yapılmış ve sonuçları Tablo 7'de gösterilmiştir.

Tablo 7'de görüleceği gibi MANOVA sonuçları, yapılan göreve göre $(\Lambda=.967, F$ hesaplanan $(5.344)=2.37, p<.04)$ yöneticilerin ve öğretmenlerin çatışma yönetimi stilleri puanlarının anlamlı olarak farklılık gösterdiğini ortaya koymuştur. Ayrıca, MANOVA uzantısında yer alan ANOVA sonuçlarına bakıldığında ise çatışma yönetimi stilleri alt boyutlarından tümleştirme ( $F$ hesaplanan $=3.91, p<.05$ ) ve ödün $(F$ hesaplanan $=7.44, p<.00)$ puanlarının da anlamlı olarak farklılık $(p<.05)$ gösterdiği bulunmuştur. 
Tablo 7. Yapılan Göreve Göre Okul Yöneticilerinin ve Öğretmenlerin Çatışma Yönetimi Stilleri Arasındaki Farklılığa İlişkin MANOVA Analiz Sonuçları

\begin{tabular}{llccccc}
\hline Kaynak & Değişkenler & $\begin{array}{c}\text { Kareler } \\
\text { Toplamı }\end{array}$ & Sd & $\begin{array}{c}\text { Kareler } \\
\text { Ortalaması }\end{array}$ & F & $\boldsymbol{p}$ \\
\hline Yapılan & Tümleştirme & 33.484 & 1 & 33.484 & $3.91^{*}$ & .05 \\
Görev & Ödün & 59.429 & 1 & 59.429 & $7.44 *$ & .00 \\
& Hükmetme & 3.808 & 1 & 3.808 & .39 & .53 \\
& Kaçınma & .578 & 1 & .578 & .04 & .84 \\
& Uzlaşma & .856 & 1 & .856 & .13 & .72 \\
\hline
\end{tabular}

Wilks' Lambda $(\Lambda)=.967 \quad$ F hesaplanan $(5,344)=2.37, p<.04$

Yapılan göreve göre okul yöneticilerinin ve öğretmenlerin çatışma yönetimi stillerinin alt boyutları olan tümleştirme ve ödün puanlarının anlamlı olarak farklılık gösterdiğine ilişkin olarak Bağımsız Gruplarda $t$ Testi yapılmış ve sonucu Tablo 8'de sunulmuştur.

Tablo 8. Yöneticilerin ve Öğretmenlerin Tümleştirme ve Ödün Stillerinin Göreve Göre Bağımsız Gruplarda $t$ Testi Sonuçları

\begin{tabular}{lccccc}
\hline Görev & $\mathbf{N}$ & $\overline{\mathrm{X}}$ & $\mathbf{s s}$ & $\mathbf{T}$ & $\boldsymbol{p}$ \\
\hline Tümleştirme & & & & & \\
$\quad$ Yönetici & 76 & 25.38 & 3.42 & 1.98 & .02 \\
$\quad$ Öğretmen & 275 & 24.63 & 2.77 & & \\
\hline Ödün & & & & & \\
$\quad$ Yönetici & 76 & 15.61 & 2.62 & 2.73 & .00 \\
Öğretmen & 275 & 14.61 & 2.88 & & \\
\hline
\end{tabular}

Tablo 8'de görüldüğg̈ gibi yöneticilerin tümleştirme puan ortalaması $(\bar{X}=25.28)$, öğretmenlerin tümleştirme puan ortalamasından $(\bar{X}=24.63)$ anlamlı düzeyde $(\mathrm{t}=1.98, p<.02)$ yüksek çıkmıştır. Yöneticilerin ödün puan ortalaması $(\overline{\mathrm{X}}=15.61)$, öğretmenlerin ödün puan ortalamasından $(\overline{\mathrm{X}}=14.61)$ anlamlı düzeyde $(\mathrm{t}=2.73, p<.00)$ yüksek çıkmıştır. Yöneticilerin tümleştirme ve ödün stili düzeyleri öğretmenlerinkinden anlamlı düzeyde yüksek çıkmıştır.

Araştırmada, medenî duruma göre okul yöneticilerinin ve öğretmenlerin çatışma yönetimi stilleri arasında anlamlı bir farklılık olup olmadığını belirlemek için MANOVA analizi yapılmış ve sonuçları Tablo 9'da gösterilmiştir. 
Tablo 9. Medenî Duruma Göre Okul Yöneticilerinin ve Öğretmenlerin Çatışma Yönetimi Stilleri Arasındaki Farklılığa İlişkin MANOVA Analiz Sonuçları

\begin{tabular}{llccccc}
\hline Kaynak & Değişkenler & $\begin{array}{c}\text { Kareler } \\
\text { Toplamı }\end{array}$ & Sd & $\begin{array}{c}\text { Kareler } \\
\text { Ortalaması }\end{array}$ & F & $\boldsymbol{p}$ \\
\hline Medenî & Tümleştirme & 24.453 & 2 & 12.226 & 1.41 & .25 \\
Durum & Ödün & 9.663 & 2 & 4.831 & .59 & .55 \\
& Hükmetme & 1.779 & 2 & .890 & .09 & .91 \\
& Kaçınma & 15.430 & 2 & 7.715 & .56 & .57 \\
& Uzlaşma & 13.669 & 2 & 6.835 & 1.02 & .36 \\
\hline
\end{tabular}

Wilks' Lambda $(\Lambda)=.984$, F hesaplanan $(10.000,688.000)=.56, p>.05$

Tablo 9'da görülen MANOVA sonuçları, medenî duruma göre $(\Lambda=.984, F$ hesaplanan $(10.000,688.000)=.56, p>.05)$ yöneticilerin ve öğretmenlerin çatışma yönetimi stilleri puanlarının alt boyutlarında anlamlı bir farkl11ık $(p>.05)$ göstermediğini ortaya koymuştur.

\section{Tartışma ve Sonuç}

Araştırmada, sosyal zekâya göre okul yöneticilerinin ve öğretmenlerin çatışma yönetimi stilleri arasında anlamlı bir farklılığın olup olmadığ incelenmiştir. Araştırmanın sonucunda, sosyal zekâsı yüksek olan yöneticilerin ve öğretmenlerin ödün stilini, hükmetme stilini ve kaçınma stilini kullandıkları bulunmuştur. Yüksek sosyal zekâya sahip olan kişi çatışma çözümüyle ilgili yapması gerekenleri yaptığı hâlde, sorun hâlen devam ediyorsa ve sorunun devam etmesi oldukça büyük sorunların doğmasına neden olacaksa çare olarak "hükmetme" stilini kullanarak çatışmanın sonlanmasını ya da ertelenmesini sağlayabilir. Bu durumda kalıcı ve sağlıklı bir çözüm için biraz daha zaman kazanmış olur. Kaçınma stili açısından, sosyal zekâ düzeyi yüksek olan yönetici ve öğretmenlerin çalışanlarla ya da öğrencilerle aralarında ortaya çıkan çatışmaları görmezden gelebilir veya karşı tarafın kazançlı çıkmasına izin verebilir. Ödün verme stili açısından bakıldığında ise yüksek sosyal zekâ düzeyine sahip olan yönetici ve öğretmenler çalışma arkadaşlarryla ve öğrencileriyle iletişimlerinde ortaya çıkan sorunların çözümünde çeşitli ödünler vererek kurumlarının başarılı sonuçlar elde etmesini sağlayabilirler. Yaşamış oldukları sorunun çözümünde tamamen kendi kazançlarına yönelik olmayıp karşı tarafın kazançlarınında kısmen de olsa gerçekleşmesinden yana davranış sergileyebilirler.

Araştırmamızdan elde edilen sosyal zekânın çatışma yönetimi stillerini 
etkilediği bulgusu, alanyazında var olan açıklamalarla benzerlik göstermektedir. Sosyal zekâsı yüksek olan insanlar, çatışmaları çözmede başarılıdırlar (Selçuk, Kayılı ve Okut, 2002). İyi iletişim kurabilme (Loflin ve Barry, 2016; Kızıltepe, 2004) ve bu iletişimi sürdürebilme becerisine sahiptirler (Doğan, Totan ve Sapmaz, 2009). Sosyal ortamlara kolayca girerler, uyum sağlarlar (Vaykos, 2015), nasıl davranacaklarını bilirler (Karadoğan, 2010). Sözel ve sözel olmayan davranışlarını etkili kullanırlar (Buzan, 2002'den akt; Doğan ve Çetin, 2009). İyi bir dinleyicidirler (Praditsang, Hanafi ve Walters, 2015), empatik yaklaşırlar (Praditsang, Hanafi ve Walters, 2015), insanların duygularını anlarlar (Gardner, 2013; Nagra, 2014). Bütün bu özellikler çatışmayı sağlıklı bir biçimde çözmek için önemlidir.

Alanyazında, sosyal zekâ ile çatışma yönetimi stilleri arasındaki ilişkiye yönelik bir araştırmaya rastlanılamamıştır. Ancak, duygusal zekâ ile çatışma yönetimi stilleri arasındaki ilişkiyi inceleyen araştırmalar mevcuttur. Chan, Sit ve Lau (2014), Carmody-Bubb, Duncan ve Ree’nin (2015), Monteiro ve Balog'un (2015), Gunkel, Schlaegel ve Taras'ın (2016) yapmış oldukları araştırmaların sonucunda, duygusal zekâ ile çatışma yönetimi stilleri arasında anlamlı ilişkiler bulunmuştur. Chan, Sit ve Lau'nun (2014) yapmış oldukları araştırmanın sonucunda, yüksek duygusal zekâya sahip olan bireylerin işbirliği, hükmetme (yarışma), uzlaşma stilini daha fazla kullandıkları bulunmuştur. Pandey, Sajjanapu ve Sangwan'in (2015) yapmış oldukları araştırmanın sonucunda, yüksek duygusal zekâya sahip olan bireylerin kaçınma stilini daha fazla kullandıkları bulunmuştur. Bu araştırma bulguları bizim araştırma bulgularımızla benzerlik göstermektedir. Araştırma bulgumuzda, yüksek sosyal zekâya sahip olan bireylerin kaçınma stilini ve ödün stilini daha fazla kullandıkları bulunmuştur. Ayrıca, alan yazında kültürel zekâ ile çatışma yönetimi stilleri arasındaki ilişkiyi inceleyen araştırma da mevcuttur. Gonçalves, Reis, Sousa ve Santos'un (2016) yapmış oldukları araştırmaların sonucunda, kültürel zekâ ile etkili çatışma yönetimi stilleri arasında anlamlı ilişkiler bulunmuştur. Yine, kişilik özellikleri ile çatışma yönetimi stilleri arasındaki ilişkiyi inceleyen Antonioni'nin (1998) yapmış olduğu araştırmanın sonucunda, dışadönüklük, açıklık, sorumluluk ve uyumluluk kişilik özellikleri ile işbirliği (bütünleştirme-tümleştirme-pazarlık) stili arasında pozitif bir ilişki bulunmuştur. Yıldızoğlu ve Burgaz'ın (2014) yapmış oldukları araştırmanın sonucunda da, okul yöneticilerinin beş faktör kişilik özellikleriyle çatışma yönetimi stili tercihleri arasında anlamlı bir ilişkinin olduğu bulunmuştur. Gelişime açıklık, yumuşakbaşl1lık/geçimlilik 
ve dişadönülük boyutuyla işbirliği (bütünleştirme-tümleştirme-pazarlık) stili arasında pozitif yönde ve orta düzeyde bir ilişki bulunmuştur.

Araştırmada, cinsiyete göre okul yöneticilerinin ve öğretmenlerin çatışma yönetimi stilleri arasında anlamlı bir farklılığın olup olmadığı incelenmiştir. Araştırmanın sonucunda, erkek yöneticilerin ve öğretmenlerin ödün stili ve hükmetme stilini kadınlardan anlamlı düzeyde daha fazla kullandıkları bulunmuştur. Hükmetme stilinin erkekler tarafından kadınlara oranla daha çok tercih edilir olmasının nedenleri erkeklere toplumun sunduğu değerler olabilir. Cinsiyet değişkenine göre yapılmış olan araştırma sonuçları farklılık göstermektedir. Araştırma bulgusu ile benzerlik gösteren Özgan'ın (2006) yapmış olduğu araştırmanın sonucunda, erkek yöneticilerin kadınlara göre hükmetme ve ödün verme stilini daha çok kullandıkları ortaya konmuştur. Öztay (2008), çalışmasında yöneticilerin çatışma yönetiminde ödün verme yaklaşımını kullanma durumlarının cinsiyete göre farklılık göterdiği bulgusuna ulaşmıştır. Akgül (2011) öğretmenlerin duygusal zekâsı ile çatışma yönetimi arasında ilişkinin olup olmadığını araştırdığı çalışmasında; cinsiyet değişkeninin kaçınma ve ödün verme stillerinde anlamlı fark elde etmiştir. Süküt (2008), araştırmasında, erkeklerin hükmetme stilini kadınlardan daha çok kullandığı sonucuna ulaşmıştır. Brewer, Mitchell ve Weber (2002) yapmış oldukları araştırmanın sonucunda, erkeksi cinsiyet rolünü benimsemiş olan bireylerin hükmetme (yarışma-üstünlük kurma) stilini kullandıkları, kadınsı cinsiyet rolü benimseyen bireylerin kaçınma (geri çekilme) stilini kullandıkları, andojen (kadınsı ve erkeksi kişilik özelliklerinin toplamı) rolünü benimsemiş bireylerin ise işbirliği stilini daha fazla kullandıklarını bulmuşlardır. Sypridon (2008) yapmış olduğu araştırmanın sonucunda, kadınların ödün stilini erkeklerden daha fazla kullandıklarını bulmuştur. Thomas, Thomas ve Schaubhut (2008) yapmış oldukları araştırmanın sonucunda, erkeklerin hükmetme (yarışma-üstünlük kurma) stilini kadınlardan daha fazla kullandıklarını bulmuşlardır. Vokić ve Sontor (2009), yapmış oldukları araştırmanın sonucunda, kadınların erkeklere göre uyma ve uzlaşma stilini daha fazla kullandıklarını bulmuşlardır. Hsi-An ve Ely’nin (2010) yapmış oldukları araştırmanın sonucunda, kadınların işbirliğini stilini erkeklerden daha fazla kullandıklarını; erkeklerin de uyma stilini kadınlardan daha fazla kullandıklarını bulmuşlardır. Buğa (2010), yapmış olduğu araştırmanın sonucunda, erkek öğretmenlerin kadın öğretmenlere göre uyma stilini daha çok kullandıklarını bulmuştur. Öte yandan Havenga (2008), Engin (2010) ve Ova'nın (2013) yapmış oldukları araştırmaların sonucunda, cinsiyete göre çatışma 
yönetimi stilleri arasında anlamlı bir farklılık çıkmamıştır.

Araştırmada, kıdeme göre okul yöneticilerinin ve öğretmenlerin çatışma yönetimi stilleri arasında anlamlı bir farklılığın olup olmadığı incelenmiştir. Araştırmanın sonucunda, yöneticilerin ve öğretmenlerin kıdemi azaldıkça ödün stili de anlamlı düzeyde azalmaktadır. Kıdemin öğretmen ve yöneticiler arasında ödün verme stili üzerinde anlamlı bir etkiye sahip olması ve kıdem arttıkça ödün verme stilinin artması; yaşam deneyimlerine, iletişim kurma becerilerine ve zaman içerisinde sosyal zekâ düzeylerini artırmış olmalarından kaynaklanmış olabilir. Sosyal zekâ insanları anlama, empati kurma, onların çalıştıkları ortamda mutlu olmalarını sağlayacak tavır ve davranışların sergilenmesini sağlayabilir. Kişi karşısındaki insana verdiği değere göre kendi isteklerinin bir bölümünden veya tümünden vazgeçebilir. Sosyal zekâsı zaman içerisinde gelişmiş olan insan karşısındaki kişiyi ikna etme becerisini elde etmiş olabilir ve bu durumda "birlikte kazanalım" deme noktasında olabilir. Kıdem değişkenine göre yapılmış olan araştırma sonuçları farklılık göstermektedir. Örneğin; Açıkgöz (2009) yapmış olduğu araştırmanın sonucunda, yöneticilik kıdemi yüksek olan okul yöneticilerin işbirliği (tümleştirme) ve ödün verme stilini daha çok kullandıklarını bulmuştur. Benzer bir sonuç Özgan (2006) tarafından yapılan ve öğretmenlerin çatışma yönetim stillerini araştıran çalışmasında elde edilmiştir. Araştırmanın sonucunda, k1demi 21 y1l ve üzeri olan öğretmenlerin kıdemi 20 y1ldan az olan öğretmenlere göre ödün verme stilini daha çok kullandıkları bulunmuştur. Ancak, Gümüşeli’nin (1994), Öztay’ın (2008) ve Vokić ve Sontor'un (2009), yapmış oldukları araştırmaların sonucunda kıdeme göre çatışma yönetimi stilleri arasında anlamlı bir farklılık bulunmamıştır.

Araştırmada, yapılan göreve gore okul yöneticilerinin ve öğretmenlerin çatışma yönetimi stilleri arasında anlamlı bir farklılığın olup olmadığı incelenmiştir. Araştırmanın sonucunda, yöneticilerin işbirliği (tümleştirme) ve ödün stili düzeyleri öğretmenlerinkinden anlamlı düzeyde yüksek çıkmıştır. Araştırma bulgusu ile benzerlik gösteren Toytok ve Açıkgöz'ün (2013); Titrek, Maral ve Barut-Kızılkaya’nın (2015) yapmış oldukları araştırmaların sonuçlarında da okul yöneticilerinin en fazla işbirliği (tümleştirme) stilini kullandıkları bulunmuştur. İşbirliği (tümleştirme) stili, demokratik yollarla çatışmaları çözmeyi hedefleyen okul yöneticilerinin, kullanmaları gereken çatışma çözme stilidir. Çatışma yönetimi ile ilgili Ova (2013) yaptı̆̆ı araştırmada insanların hiyerarşik olarak yükseldiklerinde çatışma yönetim stille- 
rinde de değişmeler yaşandığı sonucuna ulaşmıştır. Şöyle ki; emir alır konumda kaçınma yönetimini tercih eden bir kişi, emir verir konuma geldiğinde hükmetme stilini tercih etmektedir. Her ne kadar okul yöneticileri ve öğretmenlerinin iletişim içerisinde bulundukları insanlar aynı öğrenci, öğretmen ve velilerden oluşsa da; daha çok hangi grubun bireyleri ile ilişki kurdukları önemlidir. Öğretmen daha çok öğrenci ile yöneticiler ise daha çok veli ve öğretmenler ile iletişim kurarlar. Buna bağlı olarak çıkan çatışmalarda şeçilen çatışma çözme stillerinde de farklılıklar ortaya çıkar. Yönetici öğrenci, öğrenci velisi, öğretmen ve çevre ile ilgili konularda da çözümler üretme çabası içerisindedir. Bu nedenle yukarıda açıklanan nedenlerden ve etkilerden dolayı yöneticilerin öğretmenlere göre ödün verme ve tümleştirme çatışma yönetim stilini daha çok kullanmaları beklenen ve olması gereken bir sonuçtur.

Araştırmada, medenî duruma göre okul yöneticilerinin ve öğretmenlerin çatışma yönetimi stilleri arasında anlamlı bir farklılığın olup olmadığı incelenmiştir. Araştırmanın sonucunda, medenî duruma göre yöneticilerin ve öğretmenlerin çatışma yönetimi stilleri arasında anlamlı bir farklılık bulunmamıştır. Medenî durum değişkenine göre yapılmış olan araştırma sonuçları farklı1ık göstermektedir. Kırçan (2009) yaptığı araştırmanın sonucunda, bekar olan yöneticilerin evli olanlara göre işbirliği (bütünleştirme), hükmetmetme, karşılıklı ödün verme stillerini daha fazla kullandıklarını bulmuştur. Vokić ve Sontor (2009), yapmış oldukları araştırmanın sonucunda, evli olan bireylerin uyma stilini bekâr olanlardan daha fazla kullandıklarını bulmuşlardır. Al-Hamdan'ın (2009) yapmış olduğu araştırmanın sonucunda, yöneticilerin medenî durumlarına göre uyma stilini kullanmaları arasında anlamlı bir farkl1lık bulunmuştur. Boşanmış olan yöneticilerin, zorunlu olduklarında uyma stilini kullandıkları bulunmuştur. Akgül (2011) ve Ova (2013) yapmış oldukları araştırmaların sonucunda, medenî duruma göre çatışma yönetimi stilleri arasında anlamlı bir farklılık bulamamışlardır.

Genel olarak yapılmış olan bu araştırmanın sonucunda, sosyal zekâya göre öğretmenlerin ve yöneticilerin çatışma yönetimi stilleri arasında anlamlı bir farkl11ık bulunduğu için yöneticilere ve öğretmenlere sosyal zekâyı geliştirici psiko-eğitim grup çalışmalarının yapılması yarar getirecektir. Ayrıca, etkili çatışma çözme becerilerinin de kazandırılması da önemli olan diğer bir konudur. 


\section{Kaynakça}

Açıkgöz, A. (2009). Okul yöneticilerinin çatışma yönetim stilleri ile ögretmenlerin örgütsel adalet algısı arasındaki ilişki. Yayınlanmamış yüksek lisans tezi, Abant İzzet Baysal Üniversitesi Sosyal Bilimler Enstitüsü.

Akgül, G. (2011). İlköğretim okullarında görev yapan ögretmenlerin duygusal zekâ düzeyleri ile çatışma yönetimi stratejileri arasındaki ilişki. Yayınlanmamış yüksek lisans tezi, Maltepe Üniversitesi Sosyal Bilimler Enstitüsü.

Akkirman, A. D. (1998). Etkin çatışma yönetimi ve müdahele stratejileri. Dumlupınar Üniversitesi, İ.I.B.F. Dergisi, 13(11), 1-11.

Aktan, C. (1999). 2000'li yıllarda yeni yönetim teknikleri. İstanbul: Tügiad Yayını.

Albert, K. (2006). Sosyal zekâ başarının yeni bilimi. (S. Göktan, Çev.). İstanbul: Timaş Yayınları. (Orijinal çalışma basım tarihi 2013)

Al-Hamdan, Z. (2009). Nurse managers, diversity and conflict management. Diversity in Health and Care, 6, 2-13.

Altıntaş, T. (2007). İ̧̧ doyumu ve çatışma çözme stillerini etkileyen faktörlerin Incelenmesi. Yayınlanmamış yüksek lisans tezi, Ankara Üniversitesi Eğitim Bilimleri Enstitüsü.

Antonioni, D. (1998). Relationship between the big five personality factors and conflict management styles. International Journal of Conflict Management, 9(4), 336-355.

Arapkirlioğlu, H. ve Tankız, D. (2011). Müzik öğretmenliği programı özel yetenek sınavlarında alan ve yerleştirme puanlarının karşılaştırılması. E-International Journal of Educational Research, 2(4), 55-69.

Aslan, Ş. (2003). Hastane işletmelerinde örgütsel çatısma: teori ve örnek bir uygulama. Yayınlanmamış doktora tezi, Selçuk Üniversitesi Sosyal Bilimler Enstitüsü.

Asunakutlu, T. ve Safran, B. (2004) Kültürel farkl1lıklardan kaynaklanan çatişmalara yönelik bir araştırma (Marmaris turizm sektörü örneği). Dokuz Eylül Üniversitesi Sosyal Bilimler Enstitüsü Dergisi, 6(1), 26-49. 
Basım, H. N., Çetin, F. ve Tabak, A. (2009). Beş faktörlü kişilik özelliklerinin kişilerarası çatışma çözme yaklaşımlarıyla ilişkisi. Türk Psikolojisi Dergisi, 24(63), 23-34.

Bayar, A. (2015). Bir örgüt olarak okulda meydana gelen çatışma nedenleri ve çözüm yollarına yönelik okul müdürlerinin görüşleri. Sakarya University Journal of Education, 5(3), 130-141.

Brewer, N., Mitchell, P. ve Weber, N. (2002). Gender role, organizational status and conflict management styles. The International Journal of Conflict Management, 13(1), 78-94.

Buğa, A. (2010). Illköğretim okullarında görev yapan öğretmenlerin duygusal zekâ düzeyleri ile çatışma yönetimi stratejileri arasındaki ilişkinin incelenmesi. Yayınlanmamış yüksek lisans tezi, Gaziantep Üniversitesi Sosyal Bilimler Enstitüsü.

Bümen, N. T. (2004). Okulda çoklu zekâ kuramı. Ankara: Pegem.

Büyüköztürk, Ş. (2002). Sosyal bilimler için veri analizi el kitabl. Ankara: Pegem.

Büyüköztürk, Ş., Çakmak, E. K., Akgün, Ö. E., Karadeniz, Ş. ve Demirel, F. (2009). Bilimsel araştırma yöntemleri. Ankara: Pegem.

Carmody-Bubb, M. A., Duncan, P. A. ve Ree, M. J. (2015). Emotional intelligence and personality predict conflict management style: examining relationships and factor structures. Journal of Behavioral Studies in Business, 8, 1-12.

Chan, J. C., Sit E. N. ve Lau W. M. (2014). Conflict management styles, emotional intelligence and implicit theories of personality of nursing students: a cross-sectional study. Nurse Educ Today, 34(6), 934-939.

Gonçalves, G., Reis, M., Sousa, C. ve Santos, J. (2016). Cultural intelligence and conflict management styles. International Journal of Organizational Analysis, 24(4), 725-742.

Doğan, T. ve Çetin, B. (2009). Tromso sosyal zekâ ölçeği Türkçe formunun faktör yapısı, geçerlilik ve güvenirlik çalışması. Kuram ve Uygulamada Eğitim Bilimleri, 9(2), 691-720.

Doğan, T., Totan, T. ve Sapmaz, F. (2009). Üniversite öğrencilerinde benlik saygısı ve sosyal zekâ. Sakarya Üniversitesi Eğitim Fakültesi Dergisi, 
17, 235-247.

Dökmen, Ü. (2006). İletişim çatışmaları ve empati. İstanbul: Sistem Yayınc1lik.

Engin, A. (2010). Örgütlerde çatışmanın yönetimi ve bir kamu iktisadi teşebbüsünde uygulama. Yayınlanmamış yüksek lisans tezi, Gazi Üniversitesi Sosyal Bilimler Enstitüsü.

Gardner, H. (2013). Çoklu zekâ. İstanbul: Optimist Yayınları.

Goleman, D. (2014). Sosyal zekâ. İstanbul: Varlık Yayınları.

Goldstein, S. B. (1999). Construction and validation of a conflict communication scale. Journal of Applied Social Psychology, 9, 1803-1832.

Gunkel, M., Schlaegel, C. ve Taras, V. (2016). Cultural values, emotional intelligence and conflict handling styles: A global study. Journal of World Business,

Doi: 10.1016/j.jwb.2016.02.001.

Gümüşeli, A. İ. (1994). İzmir ortaöğretim okulları yöneticilerinin öğretmenler ile aralarındaki çatışmaları yönetme biçimleri. Yayınlanmamış doktora tezi, Ankara Üniversitesi Sosyal Bilimler Enstitüsü.

Gündüz, B., Tunç, B. ve İnandı, Y. (2013). Okul yöneticilerinin öfke ve stresle başaçıkma yaklaşımları ile çatışma yönetimi stilleri arasındaki ilişki. International Journal of Human Sciences, 10(1), 641-660.

Havenga, V. (2008). Gender and age differences in conflict management within small businesses. Journal of Human Resource Management, 6(1), 22-28.

Hsi-An, S. ve Ely, S. (2010). Conflict management styles, emotional intelligence, and job performance in public organizations. International Journal of Conflict Management, 21(2), 147-168.

Huan, L. J. ve Yazdanifard, R. (2012). The difference of conflict management styles and conflict resolution in workplace. Business \& Entrepreneurship Journal, 1(1), 141-155.

Karadoğan, N. B. (2010). Yöneticilerin sosyal zekâ seviyelerinin çalı̧̧anların iş doyumuna etkisi. Yayınlanmamış yüksek lisans tezi. Dokuz Eylül Üniversitesi Sosyal Bilimler Enstitüsü. 
Karip, E. (2000). Çatışma yönetimi. Ankara: Pegem.

Kızıltepe, Z. (2004). Öğretişim: Eğitim psikolojisine çağdaş bir yaklaşım. İstanbul: Merteks.

Kırçan, E. (2009). İlköğretim okulları yöneticilerinin çatışmayı yönetmede kullandıkları çatışma yönetimi stratejileri. Yayınlanmamış Yüksek Lisans Tezi, Sakarya Üniversitesi, Sosyal Bilimler Enstitüsü.

Loflin, D. C. ve Barry, C. T. (2016). You can't sit with us: Gender and the differential roles of social intelligence and peer status in adolescent relational aggression. Personality and Individual Differences, 91, 22-26.

Mayer, B. (2000). The dynamics of conflict resolution: A practitioner's guide. San Francisco: Jossey-Bass, http://www.colorado.edu/conflict/peace/example/dynconr.html.

Monteiro, M. M. ve Balogun, S. K. (2015). Psychosocial predictors of relationship conflict styles as mediated by emotional intelligence: a study of botswana adults. SAGE Open, 1-11.

Nagra, V. (2014). Social intelligence and adjustment of secondary school students. Paripex - Indian Journal of Research, 3(4), 86-87.

Ova, A. (2013). Organizasyonlardaki çatışmaların yönetimi ve bir araştırma. Yayınlanmamış yüksek lisans tezi, İstanbul Aydın Üniversitesi Sosyal Bilimler Enstitüsü.

Öner-Körüklü, N. (2010). Kişsiler arası ilişsiler ve etkili iletişim. Ankara: Pegem.

Özgan, H. (2006). İlköğretim okulu öğretmenlerinin çatışma yönetim stratejilerinin incelenmesi. Yayınlanmamış doktora tezi, Gaziantep Üniversitesi Sosyal Bilimler Enstitüsü.

Öztay, S. (2008). Illköğretim okulu yöneticilerinin çatışma yönetimi stilleri. Yayınlanmamış yüksek lisans tezi, Yeditepe Üniversitesi Sosyal Bilimler Enstitüsü.

Özülke, F. (2015). İletişim gemisinin dümeninde artık sosyal zekâ var. http://fusunozulke.com/iletisim-gemisinin-dumeninde-artik-sosyal-zek a-var. 
Pandey, S., Sajjanapu, S. ve Sangwan, G. (2015). Study on effect of emotional intelligence on conflict resolution style. Indian Journal of Science and Technology, 8(6), 71-81.

Praditsang, M., Hanafi, Z. ve Walters, T. (2015). The relationship among emotional intelligence, social intelligence and learning behaviour. Asian Social Science, 11(13), 98-107.

Renner, T. ve Feldman, R. S. (2015). Aklımın aklı: psikoloji. (M. Durak, E. Ş. Durak ve U. Kocatepe, Çev. Ed.). Ankara: Nobel. (Orijinal çalışma basım tarihi 2013)

Sarpkaya, R. (2002). Eğitim örgütlerinde çatışma yönetimi ve bir örnek olay. Kuram ve Uygulamalarda Eğitim Yönetimi, 31, 414-429.

Selçuk, Z., Kay1lı, H. ve Okut, L. (2002). Çoklu zekâ uygulamaları. Ankara: Nobel.

Sypridon, L. (2008). Conflict management styles and the gender. Yayınlanmamış doktora tezi, City University School of Business and Management.

Süküt, S. (2008). İlköğretim okulu yönetici ve öğretmenlerinin çatışma çözme stratejilerinin karşılaştırılması. Yayınlanmamış yüksek lisans tezi, Yeditepe Üniversitesi Sosyal Bilimler Enstitüsü.

Taşdan, M. ve Erdem, M. (2010). İlköğretim okulu öğretmenlerinin iş yaşami kalitesi ile örgütsel değer algıları arasındaki ilişki düzeyi. Yüzüncü $Y_{l} l$ Üniversitesi Ĕgitim Fakültesi Dergisi, 7(2), 92-113.

Terwase, J. M., Ibaishwa, R. L. ve Enemari, J. (2016). Parenting styles and gender as predictors of social intelligence among adolescents in idoma land. Mediterranean Journal of Social Sciences, 7(1), 181-187.

Thomas, K. W., Thomas, G. F. ve Schaubhut, N. (2008). Conflict styles of men and women at six organization levels. The International Journal of Conflict Management, 14(2), 1-38.

Titrek, O., Maral, M. ve Barut-Kızılkaya, D. (2015). Öğretmen görüşlerine göre ilköğretim okul yöneticilerinin kullandıkları çatışma yönetimi stratejileri. International Journal of Human Sciences, 12(2), 1734-1755.

Toytok, E. H. ve Açıkgöz, A. (2013). Öğretmen görüşlerine göre okul yöne- 
ticilerinin çatışma yönetim stilleri ile örgütsel adalet algıları arasındaki ilişki. Anadolu Ĕgitim Liderliği ve Öğretim Dergisi, 1(2), 24-36.

Türnüklü, A. (2007). Liselerde öğrenci çatışmaları, nedenleri, çözüm stratejileri ve taktikleri. Kuram ve Uygulamada Eğitim Yönetimi, 49, 129-166.

Uysal, İ. (2004). Örgütsel çatışma yönetimi ve Türkiye Cumhuriyet Merkez Bankası'na yönelik bir uygulama. Uzmanlık yeterlilik tezi, Merkez Bankası, İnsan Kaynakları Genel Müdürlüğü.

Vaykos, G. (2015). Social intelligence and self-esteem of adolescents. The Rubrics E Journal of Interdisciplinary Studies, 1(1), 19-24.

Vokić, N. P. ve Sontor, S. (2009), Conflict management styles in croatian enterprises-the relationship between individual characteristics and conflict handling styles. Working Paper Series, No: 09-05. Faculty of Economics and Business, Zagreb.

Vural, B. (2003). Öğrenci merkezli eğitim ve çoklu zeka. İstanbul: Hayat Yayınc1lı.

Weitten, W., Yost-Hammer, E. ve Dunn, D. S. (2016). Psikoloji ve çağdaş yaşam. (E. İkiz, Çev. Ed.). Ankara: Nobel. (Orijinal çalışma basım tarihi 2015)

Yaşlığlu, M., Pekdemir, I. ve Toplu, D. (2013). Duygusal zekâ ve çatışma yönetimi yöntemleri arasındaki ilişki ve bu ilişkide lider üye etkileşiminin rolü. Yönetim Bilimleri Dergisi, 11(22), 191-220.

Yıldızoğlu, H. ve Burgaz, B. (2014). Okul yöneticilerinin beş faktör kişilik özellikleriyle çatışma yönetimi stili tercihleri arasındaki ilişki. Hacettepe Üniversitesi Eğitim Fakültesi, 29(2), 295-310.

Yüksel, G. (1997). Sosyal beceri eğitiminin üniversite ögrencilerinin sosyal beceri düzeyine etkisi. Yayımlanmamış doktora tezi, Gazi Üniversitesi Eğitim Bilimleri Enstitüsü. 